\title{
Enjoyment and Entertainment in East and West
}

\author{
Matthias Rauterberg \\ Department Industrial Design, Technische Unversiteit Eindhoven, \\ Den Doelch 2, 5600 MB Eindhoven, The Netherlands \\ $\mathrm{g} \cdot \mathrm{w} \cdot \mathrm{m}$. rauterberg@tue.nl \\ http://www.ipo.tue.nl/homepages/mrauterb/
}

\begin{abstract}
From a users' perspective entertainment is based on enjoyment in using these products or services. How and which cultural differences between eastern and western cultures are influencing enjoyment and the design of entertainment technology is described in this paper. In particular the underlying religious structures are discussed and compared.
\end{abstract}

\section{Introduction}

Entertainment related to leisure activities is -in opposition to work- increasing in most industrialized countries. Even modern knowledge intensive work has to rely on intrinsic motivation, while traditional work is primarily extrinsic motivated (e.g. salary, bonus, extras, etc). In this respect all industrialized countries have to face similar challenges, but regarding enjoyment and entertainment cultural differences between western and eastern countries seems to be obvious. This paper address the issue of cultural differences and discuss possible underlying reasons.

\subsection{Playing}

Playing is one of the dominating factors of human cultures, even work, law, war, science and art contains elements of playing [5]. Playing is a specific activity in which 'learning' and 'creativity' (incl. fantasy) can come together [8]. Playing of children is an important necessity to get acquainted with reality [6]. Playing for learning is primarily process oriented, while playing for being creative is product oriented [8]. Csikszentmihalyi [4] could show how human activities can be based on intensive enjoyment, called 'flow experience'; the following conditions should be met: (1) make it a game ("look at your task as a game, establish rules, objectives, challenges to be overcome, and rewards"); (2) establish powerful goals ("as you play the game, remind yourself frequently of the overriding spiritual, social, or intellectual purpose that drive your efforts"); (3) focus ("release your mind from all distractions, from within or without; focus your entire attention on the game"); (4) surrender to the process ("let go; don't strive or strain to achieve your objective; just enjoy the process of work"); (5) accept ecstasy ("this is the natural result of the preceding four steps; it will hit you suddenly, by surprise; but there will be no mis-

M. Rauterberg (Ed.): ICEC 2004, LNCS 3166, pp. 176-181, 2004

(c) IFIP International Federation for Information Processing 2004 
taking it"); and (6) achieve peak productivity ("your ecstasy state opens vast reservoirs of resourcefulness, creativity, and energy; your productivity and quality of work shoot through the roof"). Of course, this flow experience is not always possible or even acceptable, but still very attractive and sometimes very productive.

In the past, several attempts are done to define 'playing'. According Rubinstein [15] (pp. 727-728) is human play "a result of activities that enables the human to redesign reality and to change the world. The nature of human play consists of the ability to redesign reality through mental representations". Scheuerl [19] characterized play as the origin of any activity based on the following six basic motives: (1) freedom, (2) internal infinity, (3) illusion, (4) ambivalence, (5) closure, and (6) presence. Play is at the same time familiar and alien, known and unknown. Playing was and still is an anthropological necessity for human development [6]. Play in its pure sense is 'anti-dogmatic' and 'anti-authoritarian', and can be characterized by the following three principles: (1) freedom (free choice to take part in a game), (2) equality (all players have to follow the same rules), and (3) democracy (games are open to change there rules on negotiations among players).

\subsection{Working}

In western societies an academic interest in the differences between working and playing started in the $19^{\text {th }}$ century, when the political, economical and social conditions developed into a separation of play from work [10]. This was the begin -at least in the western, industrialized societies- for establishing childhood and youth as a separate phase in child development (e.g., deliberated from child work).

The German word 'arbeit' for work has possibly its roots in the Arabic word 'arebeit' that means 'drudgery' or 'strain'. Work and in particular labor is defined by 'difficult or arduous work or effort' and related to 'pain' [20].

Table 1. The different profiles of work versus play (see Rauterberg and Paul [13])

\begin{tabular}{ll}
\hline Work & Play \\
\hline paid & not paid \\
laborious & enjoyable \\
product oriented & process oriented \\
external controlled & internal controlled \\
alienating & empowering \\
\hline
\end{tabular}

\section{Enjoyment, Religion and Culture}

Playing has meaning only in relation to non-playful activities such as work or sleep. Historically, play has been associated with joy or even ecstasy [4], wherein a kind of transcendence is experienced. Play may create an openness to a dimension of enjoyment outside the boundaries of the mundane. Berger [2] has even developed an argument for God and the supernatural from the social fact of play. The nature of 
play evokes a kind of timelessness and innocence that Berger takes to a "signal of transcendence" even within the essential patterns of human culture. Lewis [9] also argued that experiences of deep "joy" indicate a reality beyond the material, to which our souls are sometimes exposed and in which they gratefully delight.

To achieve a 'mentally enriched society' Nakastu [11] expressed clearly, that entertainment industry has to aim for a kind of entertainment technology that enable users to grow mentally (e.g., enlightment) and to avoid known pitfalls (e.g., addiction, pornography, violence, etc). Rauterberg [14] summarizes the state of the art of positive effects of existing information and communication technology (including entertainment technology) on human behavior (e.g., learning and development).

\subsection{Enjoyment and Religion}

Saroglou and Jaspard [16] have hypothesized that humor (as one aspect of enjoyment) may be negatively affected by religion. In an empirical study, Saroglou found that religiosity and religious fundamentalism (contrary to 'quest' religiosity) were negatively associated with humor creation. Saroglou and Jaspard [16] investigated in an experiment whether this association reflects causality: 85 western students were tested in their propensity to spontaneously produce humor as a response to hypothetical daily hassles after exposure to a religious video or to a humorous one vs. a non-stimulation condition. They found significant effects of experimental condition, gender, and interaction in the hypothesized direction: religious stimulation inhibited humor, while humorous stimulation promoted it. Participants' religious fundamentalism and orthodoxy predicted low humor creation in the religious condition but not in the humorous one.

Saroglou [17] could find in another study (based on pencil evaluation of humorous stimuli by 118 western participants), that religious fundamentalism and orthodoxy were found to be negatively correlated to humor appreciation in general and to appreciation of incongruity-resolution and nonsense humor in particular, whereas religious historical relativism was positively correlated to appreciation of nonsense humor (=unresolved incongruity). However, religiosity was unrelated to humor appreciation and no religious dimension predicted low appreciation of sexual humor.

Berecz [1] discusses critically the relationship of Christian sexuality and intimacy: in a western culture obsessed with sexuality as entertainment, the followers of Christ call others to view human sexuality not primarily in terms of eroticism, power, or procreation, but rather in terms of psychological intimacy.

Saroglou et al. [18] investigated 181 western adults, who were approached at the exits of bookstores to evaluate themselves on the following dimensions: adult attachment (anxiety and avoidance), 'need for closure' (preference for order and predictability), religion (classic religiosity and spirituality/emotion-based religion) and 'reading interests'. The authors found that 'need for closure' (but not attachment dimensions) predicted classic religiosity, whereas anxiety in relationships (but not avoidance) and 'preference for order' (but not predictability) predicted interest in spirituality/emotional religion. Finally, adults high in anxiety reported high interest in reading spirituality books. The authors discuss critically the 'correspondence 
model' (secure people are more religious) and emphasize the need for distinguishing between anxiety and avoidance when studying religion.

\subsection{Religion and Culture}

The western religion of Christianity was introduced into Japan in the middle of the 16th century. Christianity was generally tolerated until the beginning of the 17th century, but the Tokugawa shogunate (1603-1867) eventually proscribed it and persecuted its adherents. When relations with the west were restored in the middle of the 19th century, Christianity was reintroduced and has continued to exist in Japan till today. But still, in popular Japanese perception Christianity is regarded as a 'foreign' creed, recommending and preaching admirable ideals but unsuitable for ordinary Japanese. Because of it's 'foreign' nature, Christianity has been persecuted when demands for national unity were strong; it has been widely accepted during period of social instabilities (16th century, Meiji era, Post World war II) but once social and economical stability was reestablished interest came back. Apart from the Nagasaki region Christianity seems to be most attractive to the urban, professional classes. Various aspects of Christianity differ fundamentally from the traditional pattern of Japanese thought and outlook (e.g., monotheism versus traditional polytheism; the concept of a transcendent God versus the immanent Japanese deities; a western individual ethic versus a eastern group-orientated ethic). It is difficult to estimate whether organized Christianity can accommodate itself to the established concepts in Japan as much as Buddhism, but there still remains much potential for expressing Christian concepts in a more Japanese form (transcription from Kondansha's Encyclopedia of Japan [3] [7]).

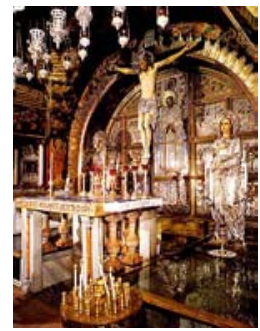

(a)

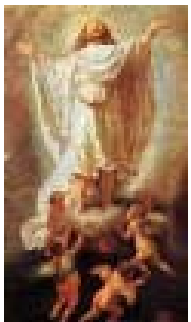

(b)

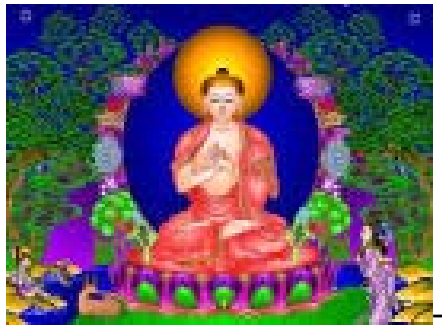

(c)

Fig. 1: Three pictures of Jesus' death (a), Jesus' ascension (b), and Buddha's enlightment (c).

One of the major difference between Christianity and Buddhism seems to be the use of important symbols: Christianity prefers the crucified and dying Christ (Fig. 1 a) while Buddhism prefers the enlightened person (Fig. 1c). At the beginning of Christianity in the western world the symbol of the ascension of Christ (Fig. 1 b) was used, but changed later to the crucified Christ. A speculative conclusion seems to be that modern Christianity relies more on anxiety than on enjoyment (see also the results of Saroglou et al. [16] [17] [18]).

Onishi and Murhpy-Shigematsu [12] could find that, unlike in Japanese society, where religion plays a relatively small role in people's everyday lives and in their 
conscious way of thinking, in Muslim societies religion has a pervasive effect on all aspects of life. In Japan, people rarely use religion to represent themselves or to categorize others. While in many western and/or eastern societies where major religious groups exist, the persons in Onishi and Murhpy-Shigematsu's study may have been socially categorized as 'Muslim immigrants', in Japan they were categorized as 'foreign workers' or just 'Asians' (coming from Bangladesh [ $\mathrm{N}=13]$, Pakistan [N=7], and Iran [N=4]; age 28-35, all male, coming to Japan at age 16-28). Although their religion is salient in Japanese society, it was not an aspect of interest for Japanese people, race and nationality assume much more importance. This focus in turn influenced the foreign respondents to emphasize these same aspects of their non-Japanese identity (e.g., getting a deeper understanding of the own religious roots).

\section{Conclusions}

We presented and discussed several interesting and important results, mainly based on scientific investigations to explore the relationships among enjoyment, religion and culture. Some of the possible conclusions are somewhat speculative: (1) Japanese strengths in entertainment technology can be related to social openness and lack of religious constrains towards enjoyment; (2) while the western entertainment industry is more focusing on the technology, the eastern is focusing on the content and narrative structure too [21]; and (3) probably entertainment technology will challenge the social and cultural norms and values more than any information and communication technology so far [22]. If content really matters (and there is sufficient evidence for) then we better take a closer look to our future vision how society should develop and aim for, and how entertainment technology can help to achieve these aims.

Acknowledgments. I have to thank the following people for our very fruitful discussions: Ryohei Nakatsu, Brad Bushman and Ben Salem.

\section{References}

[1] Berecz, J. (2002). Is there such a thing as "Christian" sex? Pastoral Psychology, Vol. 50, No. 3, pp. 139-146.

[2] Berger, P. (1990, 2nd ed). A Rumor of Angels: Modern Society and the Rediscovery of tile Supernatural. New York.

[3] Christianity in Japan, transcription from Kondansha's Encyclopedia of Japan, retrieved May 26, 2004 from http://www.baobab.or.jp/ stranger/mypage/chrinjap.htm

[4] Csikszentmihalyi, M. (1990). Flow: the psychology of optimal experience. Harpercollins.

[5] Huizinga, J. (1962). Homo ludens-vom Ursprung der Kultur des Spiels [Homo ludensthe origin of play cultur]. Hamburg (1938 first edition).

[6] Kauke, M. (1992). Spielintelligenz: spielend lernen-spielend lehren? [Play intelligence: playful learning-playful teaching]. Heidelberg.

[7] Kondansha's Encyclopedia of Japan (2004) via http://www.ency-japan.com/ 
[8] Leontjew, A. N. (1973). Probleme der Entwicklung des Psychischen [Problems of mental development]. Frankfurt.

[9] Lewis, C. S. (1965, re's ed.).The weight of glory and other addresses. New York.

[10] Nahrstedt, W. (1969). Die Entstehung der Freizeit zwischen 1750-1850-dargestellt am Beispiel Hamburg [The appearence of freetime between 1750 and 1850, described at Hamburg city]. PhD Thesis, University of Hamburg, Germany.

[11] Nakatsu, R. (2004). Entertainment Computing. Presentation, retrieved May 25, 2004 from http://www.ipo.tue.nl/homepages/mrauterb/presentations/Nakatsu(2004)/Nakatsu[2004].htm

[12] Onishi, A. \& Murhpy-Shigematsu, S. (2003). Identity narratives of Muslim foreign workers in Japan. Journal of Community \& Applied Social Psychology, Vol. 13, pp. 224-239

[13] Rauterberg, M. \& Paul, H.-J. (1990). Computerspiele - Computerarbeit: Spielerische Momente in der Arbeit [Computer game-computer work: play aspects in work]. In: F. Nake (ed.), Ergebnisse der 9.Arbeitstagung "Mensch-Maschine-Kommunikation" (Informatics Report No. 8/90, pp. 13-49). Bremen.

[14] Rauterberg, M. (2004) (in press). Positive effects of entertainment technology on human behaviour. In: Proceedings IFIP World Computer Congress (Vol. Topical Day 2). Kluwer.

[15] Rubinstein, S. L. (1977). Grundlagen der Allgemeinen Psychologie [Foundations of General Psychology]. Berlin.

[16] Saroglou, V. \& Jaspard, J.-M. (2001). Does religion affect humour creation? An experimental study. Mental Health, Religion, and Culture, Vol. 4, pp. 33-46.

[17] Saroglou, V. (2003). Humor appreciation as function of religious dimensions. Archiv für Religionpsychologie, pp. 144-153.

[18] Saroglou, V., Kempeneers, A., \& Seynhaeve, I. (2003). Need for closure and adult attachment dimensions as predictors of religion and reading interests. In P. Roelofsma, J. Corveleyn, \& J. van Saane (Eds.), One hundred years of psychology and religion (pp. 139-154). Amsterdam.

[19] Scheuerl, H. (1959). Das Spiel [The Play]. Weinheim.

[20] Word Reference (2004) via http://www.wordreference.com/

[21] Shirabe, M. \& Baba, Y. (1997). Do three-dimensional realtime interfaces really play important roles?. In: M.J. Smith, G. Salvendy \& R.J. Koubek (eds.) Design of Computing Systems: social and ergonomic considerations. Advances in Human Factors/Ergonomics, Vol. 21B, pp. 849-852.

[22] Vorderer, P., Hartmann, T. \& Klimmt, C. (2003). Explaining the enjoyment of playing video games: the role of competition. In: Proceedings of $2^{\text {nd }}$ International Conference on Entertainment Computing, ICEC 2003, ACM Digital Library. 